\title{
THE MICROPLASMA ALUMINUM AND TITANIUM OXIDATION IN CONDENSED ENVIRONMENTS
}

\author{
D.V. Vinnikov, A.N. Ozerov, V.B. Yuferov, V.T. Fomin \\ National Science Center "Kharkov Institute of Physics and Technology", \\ Kharkiv, Ukraine \\ E-mail: vinniden@gmail.com; tel.+38(057)335-63-26
}

The plant intended for the microplasma oxidation of the materials whose oxides possess semiconductor properties has been developed. The coatings consisting of corundum $\mathrm{Al}_{2} \mathrm{O}_{3}-\alpha$ (hexagonal syngony) and the two transition modifications of aluminum oxide $\mathrm{Al}_{2} \mathrm{O}_{3}-\eta$ (cubic syngony) and $\mathrm{Al}_{2} \mathrm{O}_{3}-\theta$ (monoclinic syngony) were cultivated by the aluminum substrate. The crystals in the form of anatase and rutile oxides (tetragonal syngony) were grown by the titanium substrate. The Al hardness was increased from 81 to 97 as for the HRB scale. The adhesion force for the aluminum substrate ranged from HF1 to HF3, and for the titanium substrate it was HF3. The coating morphology was established. The coatings were applied on aluminum items. The promising fields of application were defined.

PACS: $52.80 \mathrm{Wq}, 61.50 \mathrm{Cj}$

\section{INTRODUCTION}

Different coatings and different surface modification methods are used to increase the wear resistance of the parts made of aluminum, titanium and their alloys [1]. One of the methods of the surface modification prevalent recently is the method of microplasma oxidation (MPO). The essence of the process of coating application using the MPO method consists in the chemical interaction of the material with oxygen when exposed to the action of microarc that results in the formation of oxide crystals. The obtained coatings possess a high adhesion force, low porosity, increased microhardness and wear resistance and these are stable in chemically active media; the relaxations are not observed in the places of conjugation of oxidized and nonoxidized surfaces and the coating structure displays the ceramic-like behavior [2]. The coatings can be applied onto the materials whose oxides possess semiconducting properties peculiar for $\mathrm{Al}, \mathrm{Mg}, \mathrm{Ti}, \mathrm{Ta}$, $\mathrm{Nb}, \mathrm{Zr}, \mathrm{Be}$, and their alloys. Due to the acquired properties the treated parts can be used for the motor-car and aircraft construction and also for the instrumentmaking branches of industry, including the technological processes with the participation of friction pairs and rotary assemblies. Titanium oxides can be used for the water purification to remove the soot and microorganisms and provide its long-term storage with no degradation of its properties [3-5]. This method has high prospects due to its simplicity and cheapness. The topicality consists in the need for the improvement of available technologies using different plasma methods including the MPO method that allows us to increase the service life of structural materials.

The process runs at the alternating voltage of $380 \mathrm{~V}$ of the industrial frequency. The current is selected depending on the part material and its size and it is controlled by the parameters of the capacitors included into the circuit (Fig. 1). During the first seconds the process proceeds as in the case of anodic oxidation when the layer consisting both of the loosely coupled elements of treated parts and the electrolyte admixtures and components is deposited onto the part. As soon as the layer reaches a sufficient thickness, the MPO process is activated and the formed film starts to act as a barrier that is exposed to arc discharges to break it through with the flash size within one millimeter. The initial stage lasts for about $20 \mathrm{~min}$ and it results in the formation of oxides that are not interrelated with each other. At this stage, the coating thickness varies from 10 to $15 \mu \mathrm{m}$.

At the discharge point, a local heating and an increase in pressure are observed. An additional action of the alkaline environment results in an enhanced etching of the treated material in addition to an increase in the electric conductivity. The higher the percentage of alkali, the more intensive is the dissolution of the material. A certain portion of the material joins the solution and the rest of it provides the formation of the coating.

The dissociated solution consisting of $\mathrm{NaOH}$, $\mathrm{Na}_{2} \mathrm{SiO}_{3}$, and $\mathrm{H}_{2} \mathrm{O}$ provides the inflow of oxygen instead of the origination of arc that enables the oxidation of the activated surface of the piece. The available cooling system provides a rapid cooling of a formed compound with the formation of amorphous oxide film at initial stages that consists of individually arranged oxides that later on form clusters of a crystalline type. These crystal clusters form the ceramic coating. The thickness of these oxides reaches 30 to $45 \mu \mathrm{m}$. This stage lasts for about $20 \mathrm{~min}$ and it starts after $30 \mathrm{~min}$ from the beginning of the process. With the growth of the coating its insulating barrier properties are improved and the number of discharges is considerably decreased and it is even reduced to zero.

It is assumed at this stage that the coating has been formed. After $90 \mathrm{~min}$ of the MPO process the coating may contain 70 to $80 \%$ of the high-temperature ceramics. The coating thickness can reach $150 \mu \mathrm{m}$ and higher (see Fig. 1).

The most dense and refractory layer of the coating is situated underneath the coating at the interface with the metal. The entire process can last from 30 to $180 \mathrm{~min}$ and it depends on many factors including the requirements set to the final result [6]. 


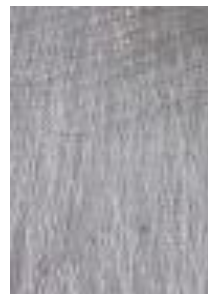

$a$

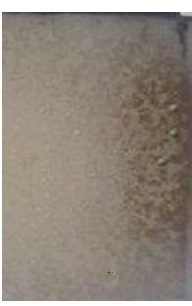

$b$

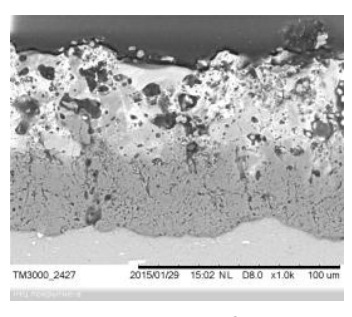

$c$
Fig. 1. The coating pattern; $a$ and $b-a$ general view of the part made of aluminium before and after the MPO treatment; $c-a$ view of the coating placed under the electron microscope (the transverse slice)

The goal of this scientific paper was to study the properties of the coatings that were obtained using the MPO method and were applied on aluminum, titanium and the items made of them and define the ways of the modernization of the developed plant and also the fields for its application.

\section{EXPERIMENTAL CONDITIONS AND THE TECHNIQUE}

The experiments were carried out using the plant given in Fig. 2,a with its schematic electric circuit and its water pumping and cooling system given in Fig. 2,b.
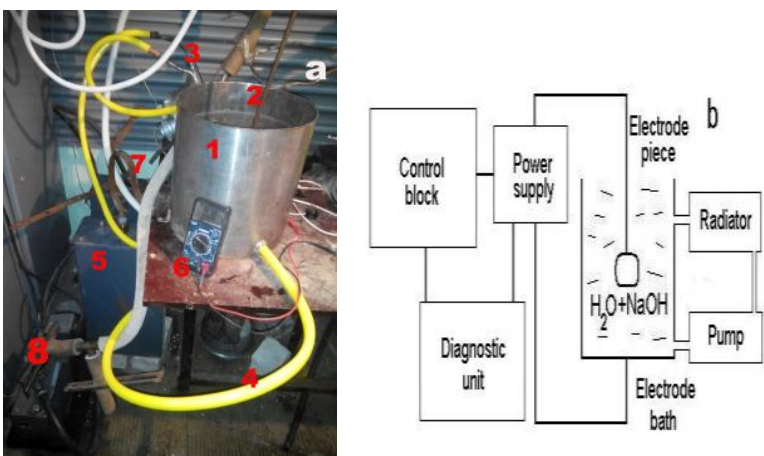

Fig. 2. The MPO process diagram: a-general view,

where 1 -the bath used as the electrode (hereinafter the electrode bath), 2 - the part used as the electrode (hereinafter the electrode piece), 3 - the radiator, 4 - the branch pipes for the electrolyte pumping, 5 - the capacitor battery, 6 - the voltmeter, 7 - the current clamps, 8 - the water pump; $b$ - the schematic electric circuit

To create the plant for the MPO process we were to meet some process requirements. The bath acting as an electrode was made of stainless steel that is resistant to the action of alkali. The surface area of the bath used as the electrode is supposed to be much larger than that of the part used as the electrode, otherwise the bath will be corroding rather fast and the electrolyte will be polluted. The part or the piece must be placed as close as possible to the bath, i. e. to the electrode, however excluding the possiblity of short-circuit. The part surface is cooled by the liquid flow. A successful application of the coating depends on the current force controlled by the capacitance value. It is desirable to maintain the temperature during the treatment at a level of $40{ }^{\circ} \mathrm{C}$. In the case of the exceed of this value it's better to let the solution get cooled.
A general view of the MPO process is given in Fig. 3.

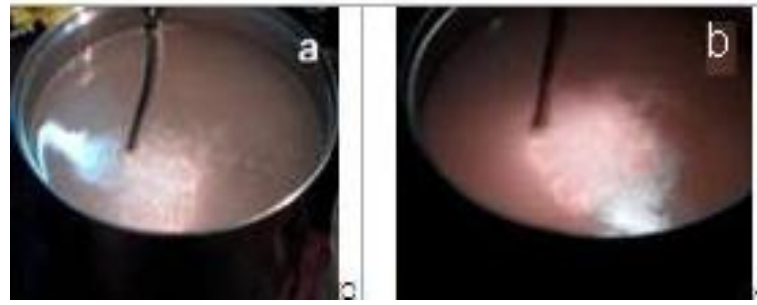

Fig. 3. The MPO process: $a$-the initial stage; $b$-the final stage

During the first few minutes the color of the arcs is brighter in comparison to that at the final stage. The number of them is higher by approximately one order of magnitude The discharge sound is louder at the completion stage, because a high voltage is required to break through the barrier in the form of built up coating. The electrolyte becomes more turbid with time due to its heating, an increased amount of oxygen in it and other electrolysis ptoducts and microarc discharges. The temperature rise rate depends on the current intensity and the electrolyte cooling rate as it is shown in Fig. 4. The temperature was changed at the steady values of operating currents, in particular for aluminum this value was equal to $8 \mathrm{~A}$ and for titanium it was equal to $17 \mathrm{~A}$. The electrolyte flow rate through thecooling system was constant, i. e. $5 \mathrm{l} / \mathrm{min}$. The liquid volume in the chamber was 181 .

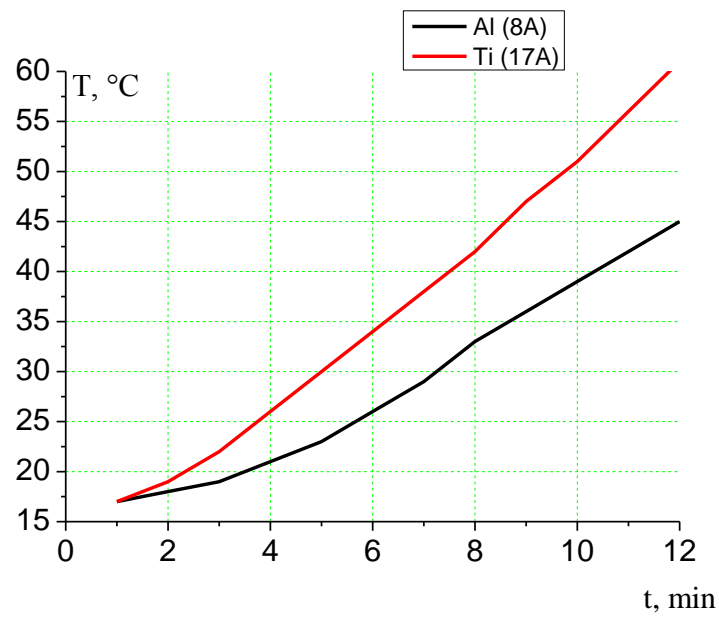

Fig. 4. The relationship of a change in the temperature as a function of time

The application of the coating onto the piece made of titanium requires high currents for the origination of microarcs and the power embedded into the discharge is two times higher. By the $12^{\text {th }}$ minute after which the voltage was cut off to cool the system the temperature of the piece made of titanium exceeded that of aluminum by $10^{\circ} \mathrm{C}$.

A change in the current follows certain mechanisms. At the initial time the medium resistance will be lower for the electrode piece, electrolyte and electrode bath path and it will be increasing with the coating build-up (Fig. 5). 


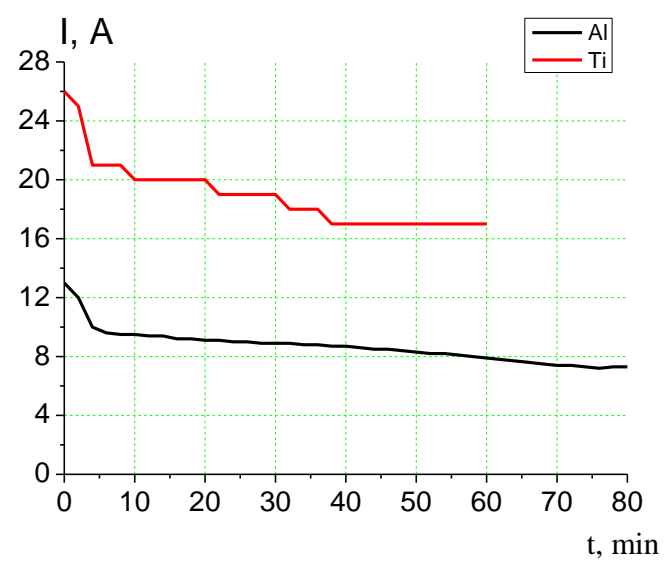

Fig. 5. The relationship of a change in the current as a function of time

The first layer of the coating is formed rather quickly, within one minute or even faster. Hence, we observe a very rapid current drop during this period of time. As the coating is built up the breakdowns appear less frequently in the places with the lowest dielectric strength. Starting from 45 or $50 \mathrm{~min}$ the process is stabilized and the current remains to be actually unchanged and it is indicative of the fact that the applied coating is uniform.

\section{RESEARCH METHODS}

To control the quality of obtained coatings the following diagnostic tools and methods were used. Diffractometric investigations were carried out using the $\mathrm{X}$-ray diffractometer DRON-4-07 in the copper $\mathrm{Cu}-\mathrm{K} \alpha$ radiation using selectively the absorbing Ni-filter. The diffracted radiation was registered by the scintillation detector. A qualitative phase analysis was done using the international database file for crystallographic compounds ICDDPDF-2. The quantitative phase analysis was done using the Rietveld method and the lattice parameters of detected phases were defined using the same method.

The adhesion force was defined using Daimler-Benz Test. Optical observations were carried out using the microscope Olympus GX-51with the magnification of $\mathrm{x} 1000$. The coating hardness was measured using the hardness gauge Rockwell TK-2M with the HRB scale. The indenter was made of steel and it had a spherical shape and the diameter of 116 inches $(1.588 \mathrm{~mm})$. The loading was $150 \mathrm{kgf}$. The coating morphology was defined using the scanning electron microscope GSM 70-01-F.

\section{RESEARCH DATA AND THEIR DISCUSSION}

\subsection{DIFFRACTOMETRIC INVESTIGATIONS}

Diffractometric investigations were carried out using the specimens made of $\mathrm{Al}$ and Ti treated by the MPO method during $50 \mathrm{~min}$ :

1. Al-specimen with the dimensions of 50x50x5 mm (the polished side).

2. Al-specimen with the dimensions of 50x50x5 mm (the unpolished side).

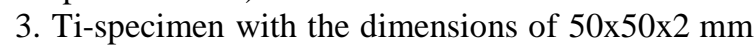
(the polished side).
4. Ti-specimen with the dimensions of $50 \times 50 \times 2 \mathrm{~mm}$ (the unpolished side).

The data on the phase composition of the specimens are given in Table 1. Figs. 6 and 7 give the diffractograms of polished specimens.

Table 1

The phase composition of specimens

\begin{tabular}{|c|c|c|}
\hline \multirow{3}{*}{ No } & Phase & Weight content, wt.\% \\
\hline \multirow{3}{*}{1} & $\mathrm{Al}_{2} \mathrm{O}_{3}-\eta$ & 66.1 \\
\cline { 2 - 3 } & $\mathrm{Al}$ & 24.9 \\
\cline { 2 - 3 } & $\mathrm{Al}_{5} \mathrm{SiO}_{10-\mathrm{x}}$ & 9.0 \\
\hline \multirow{3}{*}{2} & $\mathrm{Al}_{2} \mathrm{O}_{3-\eta}$ & 65.2 \\
\cline { 2 - 3 } & $\mathrm{Al}$ & 30.4 \\
\hline \multirow{3}{*}{3} & $\mathrm{Al}_{5} \mathrm{SiO}_{10-\mathrm{x}}$ & 4.3 \\
\hline & $\mathrm{Ti}_{-}-\alpha$ & 26.2 \\
\cline { 2 - 3 } & $\mathrm{TiO}_{2}-\mathrm{an}$ & 15.9 \\
\cline { 2 - 3 } & $\mathrm{TiO}_{2}$-ru & 57.9 \\
\hline \multirow{3}{*}{4} & $\mathrm{Ti}_{-}-\alpha$ & 31.8 \\
\cline { 2 - 3 } & $\mathrm{TiO}_{2}$-an & 16.2 \\
\cline { 2 - 3 } & $\mathrm{TiO}_{2}$-ru & 52.0 \\
\hline
\end{tabular}

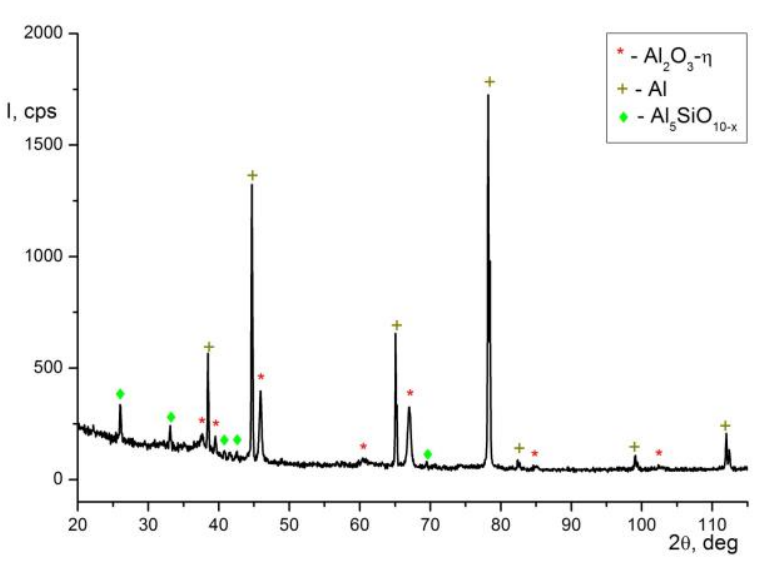

Fig. 6. Diffractogram for the specimen No 1

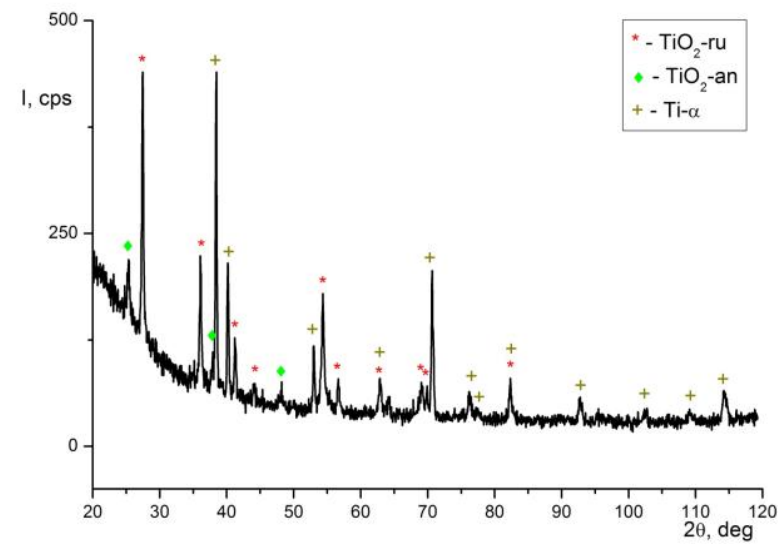

Fig. 7. Diffractogram for the specimen No 3

For the specimen No 1 (see Fig. 1) the three phases were detected: aluminum Al (the substrate), aluminum oxide $\mathrm{Al}_{2} \mathrm{O}_{3}-\eta$ and mullite $\mathrm{Al}_{5} \mathrm{SiO}_{10-\mathrm{x}}$ (it is attributed to the class of aluminosilicates with the rhombic syngony, spatial group No 55). The main phase of the specimen is 
$\mathrm{Al}_{2} \mathrm{O}_{3}-\eta$ with the weight content of $66.1 \mathrm{wt} . \%$, and the lattice parameter $a=7.895 \AA$. The content of aluminum $\mathrm{Al}$ in the specimen is $24.9 \mathrm{wt} . \%$, the lattice parameter $a=4.048 \AA$. The mullite content in the specimen is $9.0 \mathrm{wt} . \%$, the lattice parameters are as follows: $a=23.05 \AA ; b=7.62 \AA ; c=2.90 \AA$.

For the specimen No 2 (see Fig. 2) the three phases were detected: aluminum $\mathrm{Al}$ (the substrate), aluminum oxide $\mathrm{Al}_{2} \mathrm{O}_{3}-\eta$ and mullite $\mathrm{Al}_{5} \mathrm{SiO}_{10-\mathrm{x}}$. The main phase of the specimen is $\mathrm{Al}_{2} \mathrm{O}_{3}-\eta$ with the weight content of $65.2 \mathrm{wt} . \%$, and the lattice parameter $a=7.897 \AA$. The content of aluminum $\mathrm{Al}$ in the specimen is $30.4 \mathrm{wt} . \%$, the lattice parameter $a=4.049 \AA$. The mullite content in the specimen is $4.3 \mathrm{wt} . \%$, the lattice parameters are as follows: $a=23.05 \AA ; b=7.62 \AA ; c=2.90 \AA$.

For the specimen No 3 (see Fig. 3) we detected the three phases: Ti- $\alpha$ (the substrate) and the two modifications of titanium oxide, in particular rutile $\mathrm{TiO}_{2}$-ru and anatase $\mathrm{TiO}_{2}$-an. The main phase of the specimen is rutile $\mathrm{TiO}_{2}$-ru with the weight content 57.9 wt. $\%$, the lattice parameters are $a=4.588 \AA$; $c=2.957 \AA$. The anatase content $\mathrm{TiO}_{2}$-an in the specimen is $15.9 \mathrm{wt} \%$, the lattice parameters are $a=3.774 \AA$; $c=9.517 \AA$. The content of titanium Ti- $\alpha$ is $26.2 \mathrm{wt} \%$, the lattice parameters are: $a=2.951 \AA$; $c=4.681 \AA$

For the specimen No 4 (see Fig. 4) we detected the three phases: Ti- $\alpha$ (the substrate), rutile $\mathrm{TiO}_{2}$-ru and anatase $\mathrm{TiO}_{2}$-an. The main phase in the specimen is rutile $\mathrm{TiO}_{2}$-ru with the weight content $52.0 \mathrm{wt} . \%$, the lattice parameters are $a=4.584 \AA ; c=2.955 \AA$. The anatase content $\mathrm{TiO}_{2}$-an in the specimen is $16.2 \mathrm{wt} \%$, the lattice parameters are $a=3.771 \AA ; c=9.505 \AA$. The content of titanium $\mathrm{Ti}-\alpha$ is $31.8 \mathrm{wt} . \%$, the lattice parameters are: $a=2.947 \AA ; c=4.676 \AA$.

The diagram in Fig. 8 can be used to describe the phase transitions of aluminum.

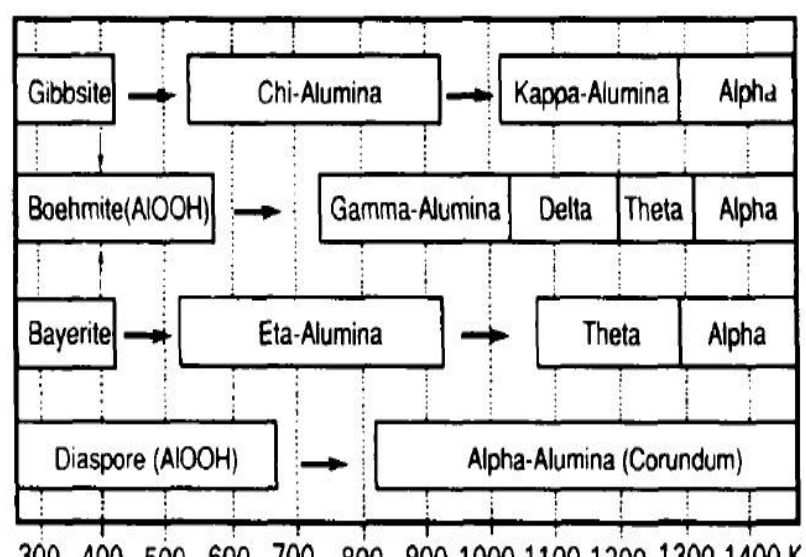

$30040050060070080090010001100120013001400 \mathrm{~K}$

Fig. 8. Thermal diagram of the phase transitions of Al (according to Vefers and Mizra, 1987) [7]

The diagram shows that $\alpha$ - and $\theta$-phases of aluminum are formed out of $\eta$-phase of aluminum at the temperatures above $900{ }^{\circ} \mathrm{C}$. Corundum $\mathrm{Al}_{2} \mathrm{O}_{3}-\alpha$ is the only stable aluminum oxide and all the rest are intermediate. These are formed during the decomposition of the different modifications of aluminum hydroxides (in the temperature range of 300 to $600^{\circ} \mathrm{C}$ ). With the rise in temperature these intermediate oxides are turned into corundum $\mathrm{Al}_{2} \mathrm{O}_{3}-\alpha$.

During the heating the titanium oxide (the anatase phase) irreversibly turns into rutile at 400 to $1000{ }^{\circ} \mathrm{C}$.

The next aluminum specimen was subjected to the MPO treatment for +30 min longer that resulted in the formation of $\alpha$-phase of aluminum. Moreover, this phase was present both on the polished (No 2) and unpolished (No 1) surfaces of treated specimen see (Table 2 and Fig. 9). Number 3 is the initial uncoated specimen.

Table 2

The phase composition of specimens

\begin{tabular}{|c|c|c|}
\hline \multirow{2}{*}{ No } & Phase & Weight content, wt.\% \\
\hline \multirow{4}{*}{1} & & 82.7 \\
\cline { 2 - 3 } & $\mathrm{Al}_{2} \mathrm{O}_{3}-\eta$ & 6.1 \\
\cline { 2 - 3 } & $\mathrm{Al}_{2} \mathrm{O}_{3}-\alpha$ & 4.3 \\
\cline { 2 - 3 } & $\mathrm{Al}_{2} \mathrm{O}_{3}-\theta$ & 6.9 \\
\cline { 2 - 3 } 2 & $\mathrm{Al}$ & 63.8 \\
\hline \multirow{3}{*}{2} & $\mathrm{Al}_{2} \mathrm{O}_{3}-\eta$ & 25.3 \\
\cline { 2 - 3 } & $\mathrm{Al}_{2} \mathrm{O}_{3}-\alpha$ & 10.9 \\
\cline { 2 - 3 } 3 & $\mathrm{Al}$ & $\approx 99$ \\
\hline \multirow{2}{*}{3} & $\mathrm{Al}$ & $\approx 1$ \\
\cline { 2 - 3 } & $\mathrm{Al}_{4} \mathrm{MnSi}_{0.74}$ & \\
\hline
\end{tabular}

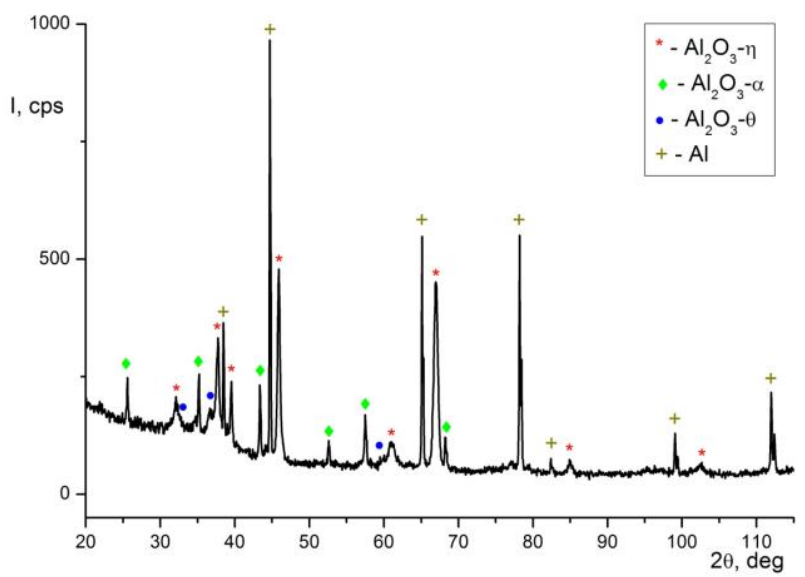

Fig. 9. Diffractogram for the specimen Al with the polished section of the surface

Hence, the MPO process duration plays an important role in the production of high temperature ceramics. The 30 -minute increase in the treatment time resulted in the formation of the coating containing $25 \%$ of the stable $\alpha$-phase of aluminum oxide.

\subsection{ADHESION FORCE AND HARDNESS MEASUREMENT}

The aluminum specimen subjected to the MPO treatment during $80 \mathrm{~min}$ showed the highest adhesion force that was defined as HF1, the specimens made of $\mathrm{Al}$ and Ti had the adhesion force of HF3 after the 50-min treatment (Fig. 10) (from top to bottom) with the magnification $\mathrm{x} 50$. 

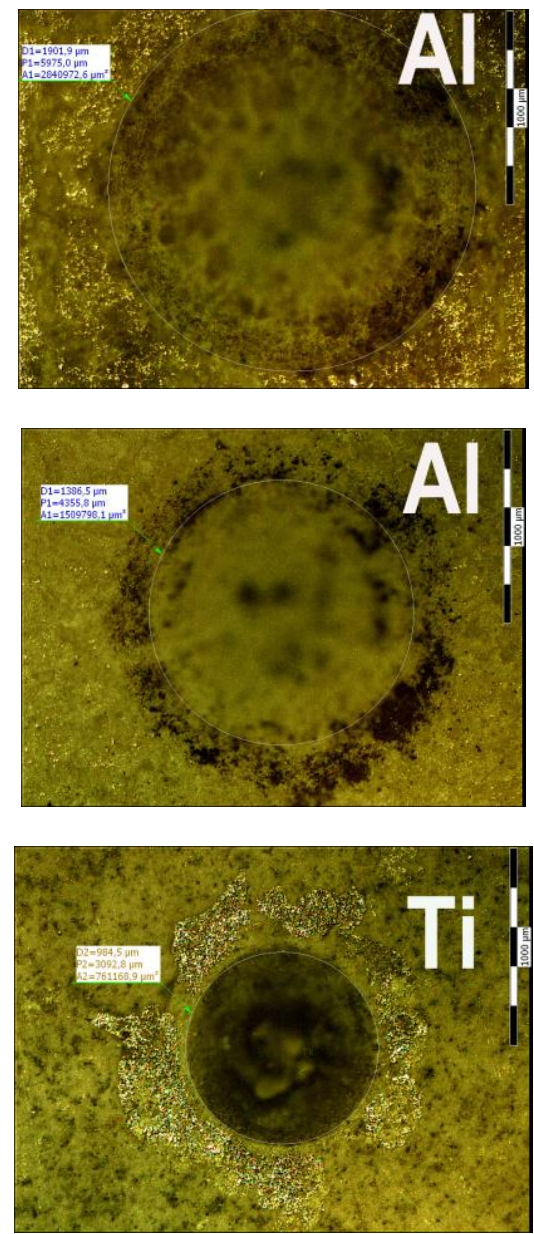

Fig. 10. Indenter traces on adhesion-tested specimens

An important fact is that the cracks are not formed on the coating during the adhesion test. We observed only the formation of powder. The worst adhesions HF5 and HF6 were observed when the removal of the loading resulted in the chopped off coating and the substrate could be easily seen. It should be noted that the MPO treated specimens have no cracks.

The hardness of the initial specimen made of $\mathrm{Al}$ was 81 to $83 \mathrm{kgf}$ and after the MPO treatment it was 95 to $97 \mathrm{kgf}$ that is peculiar for the raw steel. The hardness of $\mathrm{HRB} \geq 100$ is peculiar for solid steels.

\subsection{MORPHOLOGICAL ANALYSIS}

The morphology of the specimens made of aluminum and titanium was defined and Fig. 11 shows their general view before and after the treatment.

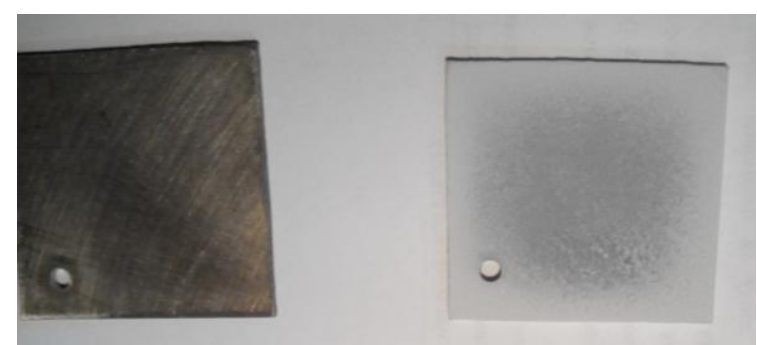

Fig. 11. The Ti-specimen before and after the MPO treatment

To remove the charge, the platinum layer was applied on the specimens during the test (Fig. 12).

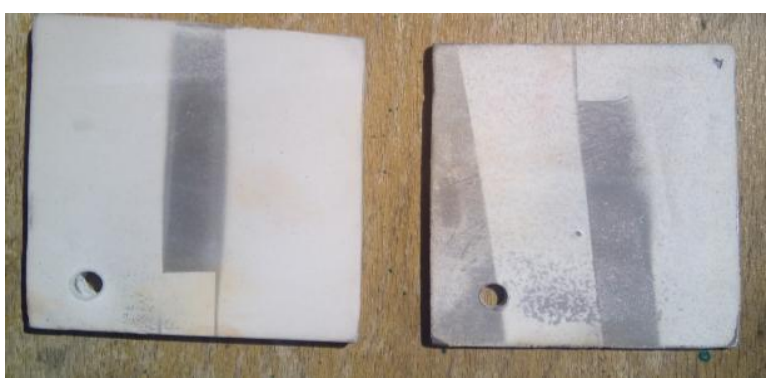

Fig. 12. The tested specimens made of Al and Ti with platinum strips

The morphology was defined in the X-ray spectrum of K-th spectral series. Table 3 with the diagram of the spectra (Fig. 14) gives the elements that were detected on the rectangular Ti-specimen section after the MPO treatment as shown in Fig. 13 together with their percentage content and atomic percentage content.

Table 3

The Ti-specimen phase composition

\begin{tabular}{|c|c|c|}
\hline Element & Weight $\%$ & Atomic $\%$ \\
\hline $\mathrm{O} \mathrm{K}$ & 51.87 & 65.97 \\
\hline $\mathrm{Na} \mathrm{K}$ & 1.95 & 1.73 \\
\hline $\mathrm{Al} \mathrm{K}$ & 0.31 & 0.23 \\
\hline $\mathrm{Si} \mathrm{K}$ & 41.61 & 30.14 \\
\hline $\mathrm{Cl} \mathrm{K}$ & 0.63 & 0.36 \\
\hline $\mathrm{Ca} \mathrm{K}$ & 0.37 & 0.19 \\
\hline $\mathrm{Ti} \mathrm{K}$ & 3.26 & 1.38 \\
\hline Totals & 100.00 & - \\
\hline
\end{tabular}

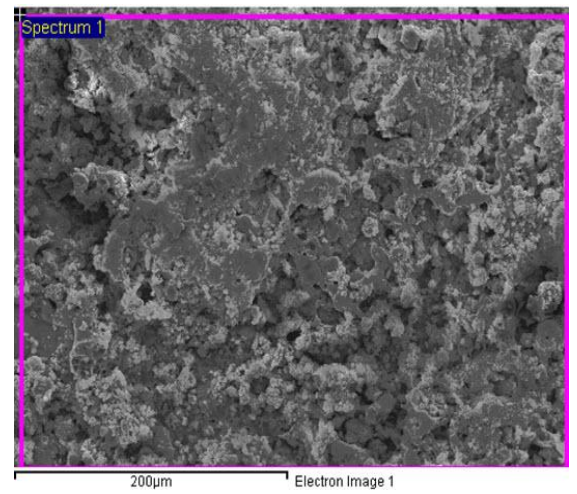

Fig. 13. Ti-specimen coating morphology

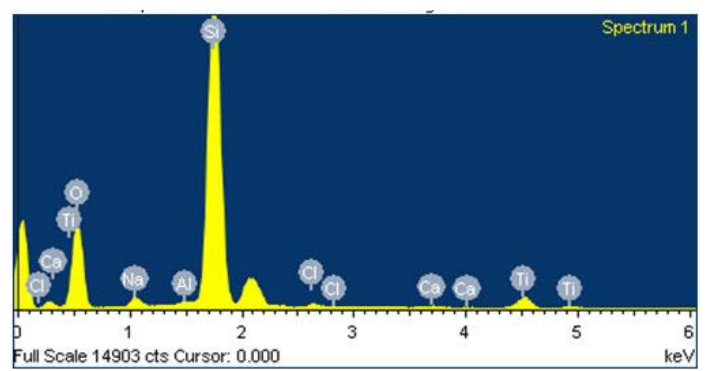

Fig. 14. The diagram of the spectra for Ti-specimen elements

The two phase domains of dark and light colors prevailing in the marked area have been detected (Figs. 15, 16). Their composition was defined (Tables 4 and 5). 
Table 4 (the tested depth is in the range of 5 to $15 \mu \mathrm{m}$ ) consists

The phase composition for the Ti-specimen coating (dark phase section)

\begin{tabular}{|c|c|c|}
\hline Element & Weight \% & Atomic \% \\
\hline O K & 49.85 & 63.83 \\
\hline Si K & 48.81 & 35.60 \\
\hline Ti K & 1.34 & 0.57 \\
\hline Totals & 100.00 & - \\
\hline
\end{tabular}

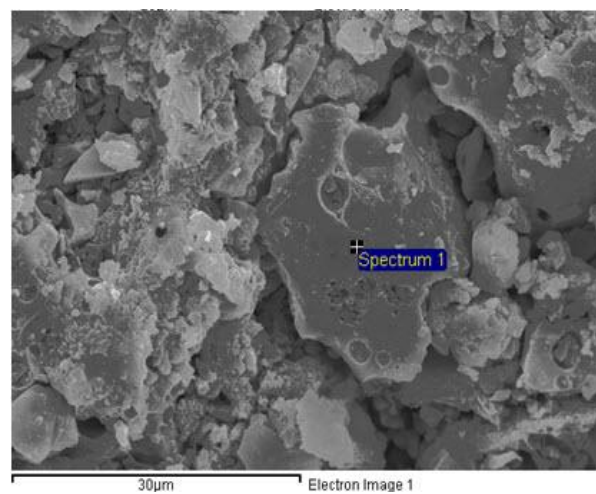

Fig. 15. Ti-specimen coating morphology (dark phase section)

Table 5

The phase composition for the Ti-specimen coating (light phase section)

\begin{tabular}{|c|c|c|}
\hline Element & Weight $\%$ & Atomic $\%$ \\
\hline $\mathrm{O} \mathrm{K}$ & 54.36 & 67.77 \\
\hline $\mathrm{Na} \mathrm{K}$ & 2.92 & 2.54 \\
\hline $\mathrm{Si} \mathrm{K}$ & 39.76 & 28.23 \\
\hline $\mathrm{Cl} \mathrm{K}$ & 1.06 & 0.60 \\
\hline $\mathrm{K} \mathrm{K}$ & 0.35 & 0.18 \\
\hline $\mathrm{Ca} \mathrm{K}$ & 0.49 & 0.24 \\
\hline $\mathrm{Ti} \mathrm{K}$ & 1.06 & 0.44 \\
\hline Totals & 100.00 & - \\
\hline
\end{tabular}

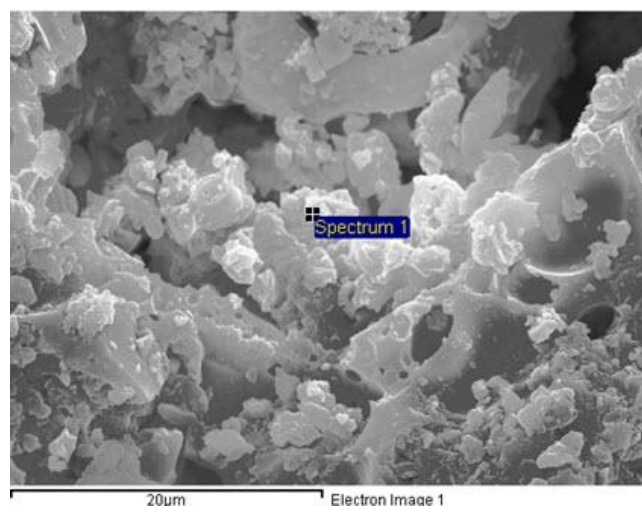

Fig. 16. Ti-specimen coating morphology (light phase section)

Oxygen and silicon are prevailing in each section in question and these appear in the coating formed by the dissociated electrolyte that includes $\mathrm{NaOH}$ and $\mathrm{Na}_{2} \mathrm{SiO}_{3}$.

Similar pattern is observed on the aluminum coating. Oxygen, silicon and aluminum are prevailing both for the dark and light phases (see Table 6 and Fig. 17).

Based on the morphological research data we can draw a conclusion that the surface layer of the coating of the decomposition products of electrolyte components.

Table 6

The phase composition for the Al-specimen coating

\begin{tabular}{|c||c|c|}
\hline Element & Weight \% & Atomic \% \\
\hline $\mathrm{O} \mathrm{K}$ & 45.35 & 59.09 \\
\hline $\mathrm{Na} \mathrm{K}$ & 2.00 & 1.81 \\
\hline $\mathrm{Al} \mathrm{K}$ & 18.21 & 14.07 \\
\hline $\mathrm{Si} \mathrm{K}$ & 32.42 & 24.06 \\
\hline $\mathrm{Cl} \mathrm{K}$ & 0.56 & 0.33 \\
\hline $\mathrm{K} \mathrm{K}$ & 0.30 & 0.16 \\
\hline $\mathrm{Ca} \mathrm{K}$ & 0.34 & 0.18 \\
\hline $\mathrm{Mn} \mathrm{K}$ & 0.38 & 0.15 \\
\hline Fe K & 0.43 & 0.16 \\
\hline Totals & 100.00 & - \\
\hline
\end{tabular}

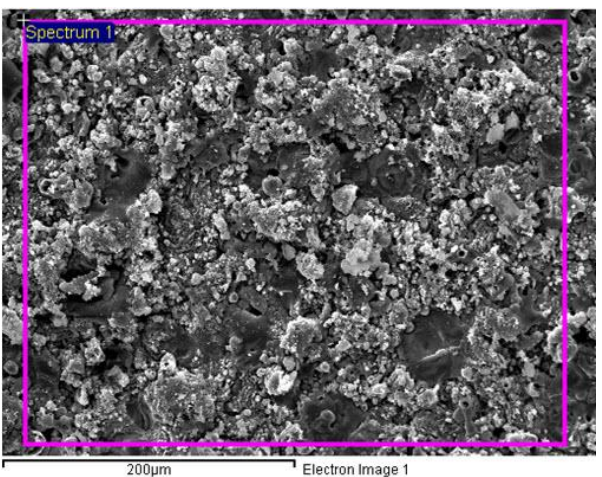

Fig. 17. Al-specimen coating morphology

\subsection{MPO PROCESS HANDS-ON APPLICATION}

Large-scale production items were subjected to the MPO treatment. The coating was applied during one hour. The parts made of aluminum and its alloys were used as the specimens. The coatings were successfully applied on the parts with the complicated relief, thread connections and cavities. Fig. 18 shows the obtained results.
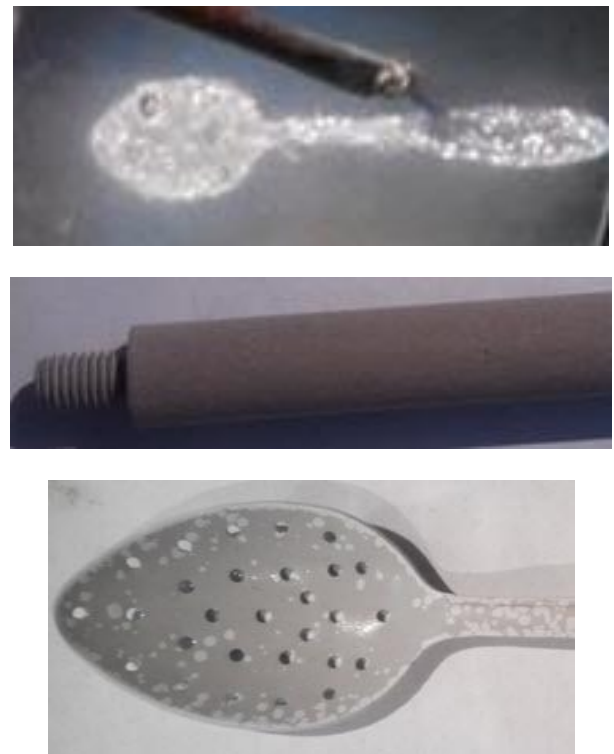

Fig. 18. Al-specimens in the process of coating application and with the applied coating 


\section{CONCLUSIONS}

The plant with the cooling system was developed to carry out the MPO process. Time and temperature modes were defined for the process to form corundum coatings. The X-ray structure analysis and DaimlerBenz Test were carried out, the specimen hardness was measured and the coating morphology was studied. Aluminum specimens showed the availability of corundum coating with a high adhesion degree to them. The oxide coating obtained on the titanium substrate had a lower adhesion and it is conditioned by the insufficient values of arc currents. In addition to the plate-like substrates, the industrial specimens of a complicated shape with difficult-to-access places and thread connections were also subjected to the MPO treatment to show as an example a wide field of application of the MPO process for industrial purposes. In all the cases the coating shows a sufficient reliability. The specimens with titanium oxides require additional studies due to their antiseptic properties. The operating modes of the plant should be improved and optimized.

\section{REFERENCES}

1. Friction, Wear and Lubrication / Ed. by I.V. Kragelsky, V.V. Alysin M.: "Machinostroienie", 1979, $358 \mathrm{p}$.

2. E.A. Kryvonosova, A.I. Gorchakov, Y.V. Shcherbakov. The Structure and Properties of Coatings Subjected to Microarc Oxidation // The Welding Production. 2013, N 10, p. 27-31.

3. Center for Chemical Technologies. Titanium Dioxide Properties.

http://chemicalmaterials.ru/svojstva_dioksid_titana.

4. A.I. Gorchakov, E.A. Kryvonosova. On the Issue of the Formation of the Pores in the Coatings Exposed to the Microarc Oxidation // Heavy Engineering Industry. 2008, N 7, p. 26-29.

5. E.A. Krivonosova, A.I. Gorchakov. The Microarc Oxidation as an Efficient Technology used for the Increasing of the Wear Resistance of Aluminum Alloys // Elektrotechnical Electronica E+E. 2013, N 5, 6, p. 57-59.

6. I.V. Suminov et al. Microarc Oxidation (Theory, Technology and Equipment). M.: "Ecomet", 2005, $368 \mathrm{p}$.

7. R.-S. Zhou, R.L. Snyder. Structures and transformation mechanisms of the $\eta, \gamma$, and $\theta$ transition aluminas // Acta Cryst. 1991, v. 47, p. 617-630.

\title{
МИКРОПЛАЗМЕННОЕ ОКСИДИРОВАНИЕ АЛЮМИНИЯ И ТИТАНА В КОНДЕНСИРОВАННЫХ СРЕДАХ
}

\author{
Д.В. Винников, А.Н. Озеров, В.Б. Юферов, В.Т. Фомин
}

Создана установка для осуществления процесса микроплазменного оксидирования материалов, оксиды которых обладают полупроводниковыми свойствами. Получены покрытия на алюминии, состоящие из корунда $\mathrm{Al}_{2} \mathrm{O}_{3}-\alpha$ (гексагональная сингония) и двух переходных модификаций оксида алюминия: $\mathrm{Al}_{2} \mathrm{O}_{3}-\eta$ (кубическая сингония) и $\mathrm{Al}_{2} \mathrm{O}_{3}-\theta$ (моноклинная сингония). На титане получены кристаллы в виде оксидов анатаза и рутила (тетрагональная сингония). Для Al твердость по шкале HRB выросла с 81 до 97. Сила адгезии для алюминия - HF1...HF3, для титана - HF3. Получена морфология покрытий. Проведено нанесение покрытий на алюминиевые изделия. Обозначены дальнейшие применения.

\section{МІКРОПЛАЗМОВЕ ОКСИДУВАННЯ АЛЮМІНІЮ ТА ТИТАНУ В КОНДЕНСОВАНИХ СЕРЕДОВИЩАХ}

\author{
Д.В. Вінніков, А.М. Озеров, В.Б. Юферов, В.Т. Фомін
}

Створена установка для здійснення процесу мікроплазмового оксидування матеріалів, оксиди яких мають напівпровідникові властивості. Отримано покриття на алюмінії, що складаються 3 корунду $\mathrm{Al}_{2} \mathrm{O}_{3}$ - $\alpha$ (гексагональна сингонія) і двох перехідних модифікацій оксиду алюмінію: $\mathrm{Al}_{2} \mathrm{O}_{3}$ - (кубічна сингонія) i $\mathrm{Al}_{2} \mathrm{O}_{3}-\theta$ (моноклінна сингонія). На титані отримані кристали у вигляді оксидів анатазу $\mathrm{i}$ рутилу (тетрагональна сингонія). Для Al твердість за шкалою НRB зросла 381 до 97. Сила адгезії для алюмінію HF1...HF3, для титану - HF3. Отримана морфологія покриттів. Проведено нанесення покриттів на алюмінієві вироби. Позначені подальші застосування. 